\title{
POŚTA
}

TELEKOMUNIKÁCIE A

ELEKTRONICKY OBCHOD

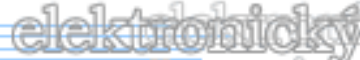

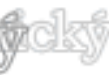

ELEkन

\section{DAŇ Z PRÍJMOV PRÁVNICKÝCH OSÔB VO VYBRANÝCH KRAJINÁCH}

\author{
Lucia Krátka*
}

Úvod

Daňová politika Európskej únii ako jedna z mála oblastí podlieha jednomysel'nému schval'ovaniu v Rade, a teda všetky zmeny a nové iniciatívy musia získat' súhlas všetkých členských štátov. Namiesto legislatívnych návrhov v tomto prípade Európska komisia využíva formu odporúčaní.

Hlavnými ciel'mi daňových iniciatív EÚ sú:

- zlepšenie fungovania jednotného trhu,

- odstránenie prekážok vyplývajúcich z paralelnej existencie národných daňových systémov členských krajín,

- zvýšenie konkurencieschopnosti európskych firiem,

- zlepšenie spolupráce národných daňových úradov,

- boj proti daňovým podvodom, ktoré ochudobňujú štátne kasy členských štátov.

Priame dane, predovšetkým dane z príjmu fyzických a právnických osôb, sú plne v kompetencii národných vlád. Rozhodujú o výške sadzieb, spôsobe výpočtu daňového základu, výnimkách a oslobodeniach od daňovej povinnosti.

EÚ zasahuje do oblasti priamych daní len v prípadoch, ked' môžu byt' ohrozené záujmy jednotného trhu a plne rešpektuje princíp subsidiarity - riešenie z európskej úrovne je možné len vtedy, ked' samostatné konanie jednotlivých členských štátov nemôže priniest' efektívne riešenie. Legislatíva EÚ však zaväzuje členské štáty zdiel'at' informácie, ktoré sú nevyhnutné na boj proti finančným a daňovým podvodom. [6]

Úlohou daňovej politiky EÚ je zabezpečit', aby boli daňové predpisy v súlade s ciel'mi zvyšovania zamestnanosti a konkurencieschopnosti EÚ, ako aj s ciel'mi jednotného trhu a vol'ného kapitálu.

Všetky členské štáty EÚ musia udržiavat' zdravý stav svojich verejných financií. Je na členských štátoch, aké priority si stanovia na strane výdavkov a aké dane použijú na krytie týchto výdavkov, podmienkou však je, aby boli v súlade so zásadami jednotného trhu a vol'ného pohybu kapitálu a aby nevytvárali prekážky cezhraničným investíciám. To členským štátom ponecháva priestor, aby si sami stanovovali sadzby dane z príjmov právnických osôb. Túto nezávislost' členských štátov podporujú i pravidlá EÚ. [3]

\footnotetext{
${ }^{*}$ Ing. Lucia Krátka, Žilinská univerzita v Žiline, Fakulta prevádzky a ekonomiky dopravy a spojov, Katedra spojov, Univerzitná 1, 01026 Žilina e-mail: lucia.kratka@fpedas.uniza.sk
} 


\section{Daň z príjmov právnických osôb v Mad’arsku}

Mad'arský daňový systém je založený na priamych daniach (daniach z príjmov právnických a fyzických osôb) doplnených $\mathrm{v}$ oboch prípadoch platením príspevkov na sociálne poistenie, ale aj platením majetkových a nepriamych daní.

$\mathrm{V}$ posledných rokoch bola v Mad'arsku silná tendencia znižovania daňových sadzieb, a to najmä v nových členských štátoch. $V$ tejto súvislosti si Mad'arsko vybudovalo postavenie ako krajina s nízkym zdanením vzhl'adom na to, že sa zaviedla sadzba dane z príjmov právnických osôb už v roku 1995 vo výške $18 \%$ a d'alej bola znížená v roku 2004 na $16 \%$. Od roku 2010 bol zavedený širší základ dane a daňová sadzba bola zvýšená na 19\%, ale zároveň bola prerušená $4 \%$ daň solidarity (solidárna prirážka) s výsledkom, že efektívne daňové zat’aženie sa zníži približne o jeden percentuálny bod. V súčasnosti sa stále za určitých podmienok používa $10 \%$ sadzba dane, a to na tú čast' základu dane, ktorá neprekročí HUF 50 mil. (184 $500 €)$.

Ďalšou formou dane $\mathrm{z}$ príjmu právnických osôb môže byt' $\mathrm{v}$ prípade zákonom povolených podmienok tzv. zjednodušený daňový režim pre spoločnosti s ručením obmedzeným, verejné a komanditné spoločnosti, družstvá, tak isto ako pre individuálneho podnikatel'a. Tento daňový režim nahradzuje dane z príjmov, zrážkovú daň aj daň z pridanej hodnoty. V prípade použitia tohto režimu sa uplatňuje jednotná daň z obratu zvýšeného o DPH a prípadne upraveného o vybrané položky, ktorá bola zvýšená z $15 \%$ na $25 \% \mathrm{v}$ roku 2006 a neskôr na 30\% v roku 2010.

Okrem dane z príjmov môžu obce vyberat' miestnu podnikatel'skú daň, ktorej výšku určujú miestne úrady, maximálne však do výšky 2\%. Od roku 2004 sú spoločnosti povinné platit' inovačnú daň, ktorá je od roku 2007 vo výške $0,3 \%$. Inovačná daň je daňovo uznatel'ným výdavkom, naopak miestna podnikatel'ská daň nie je. Na podporu výskumu a vývoja sú tieto náklady (náklady na inovačnú daň) od 1. januára 2010 odpočítatel’né z miestnej podnikatel'skej dane. Mikropodniky a malé podniky sú oslobodené od platenia inovačnej dane.

Kapitálové zisky sú obvykle zahrnuté do celkových príjmov spoločnosti. Avšak $50 \%$ z kapitálových ziskov (z transakcií na uznávanej burze cenných papierov) spoločnosti inej ako poist'ovňa alebo finančná inštitúcia sú oslobodené, s výhradou obmedzení. Od 1. januára 2010, kapitálové zisky zahraničných spoločností bez stálej prevádzky v Mad'arsku sú predmetom zdanenia na úrovni súkromnej osoby (vlastníka), ak vlastnícky/hlasovací podiel osoby dosiahne $25 \%$. Dividendy vyplácané mad'arským spoločnostiam sú vo všeobecnosti odpočítatel'né od základu dane z príjmov právnických osôb.

Subjekty, ktoré podliehajú dani z príjmov právnických osôb:

- subjekty, ktoré boli založené podl'a mad’arského práva,

- podniky vytvorené na základe obchodného práva (akciové spoločnosti, spoločnosti s ručením obmedzeným, joint ventures, verejná obchodná spoločnost', komanditná spoločnost'),

- európska spoločnost' a družstevná európska spoločnost',

- družstvá a štátne podniky,

- nadácie a vzájomné poistné fondy,

- spoločnosti právnikov, notárov, exekútorov a advokátov,

- zahraničné spoločnosti, ktoré majú miesto svojho riadenia v Mad'arsku a nie sú považované za rezidenta v krajine svojho sídla.

Zdanitel’ným príjmom sú všetky typy príjmov vrátane príjmov z obchodných aktivít a všetky výdavky spojené s prevádzkou podniku sú odpočítatel'né. 
Odpisovanie hmotného obchodného majetku je povinné, pozemky sa naopak neodpisujú. Nehmotný majetok sa môže odpisovat' podl'a účtovných pravidiel.

Zdanitel’ným obdobím je kalendárny rok a daňové priznanie sa podáva do 31 . mája nasledujúceho roku. $[2,6]$

\section{Daň z príjmov právnických osôb v Českej republike}

Daňovou sústavu Českej republiky tvorí daň z pridanej hodnoty, spotrebná daň vrátane energetických daní, dane z príjmov, daň z nehnutel'nosti, cestná daň, daň dedičská, darovacia a z prevodu nehnutel'ností. Medzi d'alšie odvody daňového charakteru patrí najmä poistné na sociálne zabezpečenie a verejné zdravotné poistenie a miestne poplatky. [2]

Daň z príjmov právnických osôb vznikla ako náhrada predchádzajúcich odvodov zo zisku, dôchodkovej a pol'nohospodárskej dane. Daň z príjmu sa vyberá predovšetkým u právnických osôb ako sú spoločnosti s ručením obmedzeným a komanditné spoločnosti. Právnické osoby so sídlom v Českej republike sú predmetom daňovej povinnosti, ktorá súvisí s príjmami plynúcimi zo zdrojov v Českej republike a zo zdrojov v zahraničí.

Sadzba dane z príjmov sa postupne znižovala z 24\% v roku 2007 na 19\% v roku 2010. Sadzba zrážkovej dane je pre všetkých $15 \%$ a znížená sadzba je 5\%. 15\% sadzba sa vzt’ahuje na úroky, dividendy, licenčné poplatky pre obyvatel'ov aj nerezidentov a pre obe spoločnosti a jednotlivca. Vyplatené dividendy a zisky z kapitálu pochádzajúce zo strany materských spoločností registrovaných v členskom štáte EÚ, sú oslobodené od zrážkovej dane. Dividendy a úroky vyplácané kvalifikovaným zahraničným penziám môžu byt' oslobodené od zrážkovej dane. Okrem toho kvalifikované zahraničné penzijné fondy môžu využívat' zníženú 5\% sadzbu dane z príjmov právnických osôb. [6]

Predmetom dane sú vo všeobecnej rovine príjmy, resp. výnosy zo všetkých činností a z nakladania s celým majetkom. Poplatníci, ktorí nie sú zriadení alebo založení za účelom podnikania, nie sú predmetom dane príjmy z činnosti vyplývajúcich $\mathrm{z}$ ich poslania. U celej rady d'alších subjektov existujú významné odlišnosti v spôsoboch zdaňovania. Jedná sa najmä o investičné fondy, dôchodkové fondy, verejné vysoké školy, banky, bytové družstvá, zdravotné poistovne, odborové organizácie a štátne fondy.

Poplatníkmi dane sú osoby, ktoré nie sú fyzickými osobami, a organizačné zložky štátu. Poplatníci, ktorí majú na území Českej republiky sídlo alebo miesto svojho vedenia, majú daňovú povinnost' z celosvetových príjmov; poplatníci, ktorí nemajú na území štátu svoje sídlo, majú daňovú povinnost' len z príjmov plynúcich zo zdrojov na území Českej republiky.

Základ dane sa odvodzuje od výsledku hospodárenia pred zdanením, ktorý sa podstatne upravuje. Základ dane je rozdiel, o ktorý príjmy, s výnimkou príjmov, ktoré nie sú predmetom dane alebo sú oslobodené, prevyšujú výdavky (náklady). Základ dane sa znižuje o daňovú stratu (tá môže byt' uplatňovaná maximálne v piatich nasledujúcich zdaňovacích obdobiach po období za ktoré bola vymeraná), možno od neho odpočítat' $100 \%$ výdajov vynaložených na realizáciu projektu výskumu a vývoja. Od takto upraveného daňového základu je možné odpočítat' dary. [2]

Zdanitel'ným obdobím je kalendárny rok alebo hospodársky rok, ktorý nemusí byt' totožný s kalendárnym. Daňové priznanie sa podáva do konca tretieho mesiaca po skončení zdaňovacieho obdobia. Výnimku tvoria právnické osoby podliehajúce povinnému auditu alebo osoby, ktorých daňové priznania spracováva a predkladá daňový poradca, ktoré podávajú daňové priznanie až do konca šiesteho mesiaca po skončení zdaňovacieho obdobia. Posledný deň lehoty pre podanie daňového priznania je súčasne aj dňom splatnosti dane. [2] 


\section{Daň z príjmov právnických osôb v Pol'sku}

Pol'ský daňový systém je založený na priamych daniach (daň z príjmov právnických a fyzických osôb je prepojená klasickým systémom, podl'a ktorého je príjem právnických osôb plne zdaňovaný na úrovni podnikov a rozdelené zisky navyše podliehajú dani z príjmov fyzických osôb u akcionárov), sociálnom poistení, nepriamych a majetkových daniach. [2]

Od roku 1995 bolo prijatých niekol'ko opatrení voblasti zdaňovania príjmov právnických osôb. Počas posledných rokov bola daň z príjmov právnických osôb znížená popri dani z príjmov fyzických osôb, najmä daňové sadzby boli výrazne znížené postupne až na úroveň $19 \%$ zo 40\% v roku 1996. Základ dane bol rozšírený o obmedzenia alebo zrušením rôznych systémových stimulov, investičných úverov a nehnutel'nosti (súvisiace daňové úkryty). Odpisy na daňové účely boli podané bližšie, aby dosiahli súlad s ekonomickými odpismi a počet odpisových plánov bol drasticky znížený. Niektoré zmeny boli vykonané v zákone o dani z príjmov s ciel’om prispôsobit' ho regulácii EÚ v oblasti priamych daní.

Pol'ský systém dane z príjmov právnických osôb je klasický daňový systém. Príjmy spoločnosti sú plne zdanené na úrovni spoločnosti, s rozdelením zisku sú zdanené opät' formou konečnej zrážkovej dane v rukách akcionárov. Sadzba dane z príjmov právnických osôb je 19\% a uplatňuje sa na príjmy a kapitálové zisky. Kapitálové zisky sú pridané k celkovým bežným príjmom. Daňové právne predpisy stanovujú zoznam neodpočítatel'ných výdavkov (napr. výdavky na reprezentáciu). Od 1. januára 2007 dary pre verejné organizácie registrované v Pol'sku alebo v inej krajine EHP (členské štáty EÚ, Island, Lichtenštajnsko a Nórsko), rovnako ako dary pre náboženské účely sú odpočítatel'né zo zdanitel'ných príjmov do výšky maximálne $10 \%$ z príjmov. Daňové straty môžu byt' prevádzané 5 rokov a nie je povolená ako odpočítatel'ná položka. Kompenzácia nesmie presiahnut' $50 \%$ straty v každom roku.

V roku 2007 bola zavedená nová regulácia aplikovaná na malých daňovníkov a začínajúce firmy. To umožňuje jednorazový odpis určitého dlhodobého majetku. Odpočet sa koná v roku, kedy je zaznamenaný dlhodobý majetok. Od roku 2009 bola zvýšená maximálna výška odpočtu z $50000 €$ na $100000 €$.

Právnickými osobami, ktoré podliehajú dani z príjmov právnických osôb sú akciové spoločnosti, spoločnosti s ručením obmedzeným, štátne podniky a družstvá, európska spoločnost' a európska družstevná spoločnost', naopak investičné a dôchodkové fondy sú od dane oslobodené. Náklady vynaložené na získanie zdanitel'ných príjmov sú odpočítatel'né, ak zákon neustanovuje inak. Medzi daňovo uznatel'né výdavky patria aj platby sociálneho poistenia a dane $\mathrm{z}$ nehnutel'nosti.

Odpisy sú v Pol'sku povinné (okrem pôdy, umeleckých prác, múzejných exponátov a nenakúpeného goodwillu) a nemožno ich odložit'. Všeobecne sa vyžaduje lineárna metóda odpisovania. Majetok, ktorý môžeme odpisovat' zrýchlene, je taxatívne vymedzený v zákone a zahŕňa najmä stroje a zariadenia použité v chemickom priemysle, pol'nohospodárstve alebo v potravinárskom priemysle.

Daňové stimuly zahŕňajú možnost' rýchlejších odpisov vo výrobných podnikoch a zvýhodnenie v malých podnikoch do ročného obratu $800000 €$ vrátane DPH. V Pol'sku d’alej existuje 14 špeciálnych ekonomických zón, v ktorých môže podnikajúci investor (pokial' prefinancuje viac než 100000 Eur) získat' pomoc vo výške 50\% kvalifikovaných výdavkov.

Daňovú stratu možno uplatňovat' najdlhšie v nasledujúcich 5 rokoch, v jednotlivých rokoch je môžné odpočítat' $50 \%$ hodnoty straty. [2,6] 


\section{Daň z príjmov právnických osôb v Slovenskej republike}

Daňovú sústavu Slovenskej republiky legislatívne vymedzuje zákon o daniach z príjmov, zákon o dani z pridanej hodnoty, zákony o spotrebných daniach a zákon o miestnych daniach a miestnych poplatkoch. Miestnymi daňami, ktoré vyberá obec sú daň z nehnutel'ností, daň za psa, daň z ubytovania, daň za užívanie verejného priestranstva, daň za predajné automaty, daň za nevýherné hracie prístroje, dan̆ za vjazd a zotrvanie motorového vozidla, daň za jadrové zariadenia a poplatok za komunálne odpady a drobné stavebné odpady. K dôležitým odvodom patrí najmä sociálne poistenie.

Predmetom dane sú príjmy právnických subjektov, predovšetkým akciových spoločností, spoločností s ručením obmedzeným a družstiev. Predmetom dane tzv. správcovských spoločností, investičných a podielových fondov, poplatníkov, ktoré nie sú zriadené alebo založené za účelom podnikania, verejných obchodných spoločností, komanditných spoločností, NBS a Fondu národného majetku SR sú len niektoré dosiahnuté príjmy. Od dane sú oslobodené príjmy záujmových združení právnických osôb, profesijných komôr, občianskych združení vrátane odborových organizácií, atd’. Od dane sú taktiež oslobodené úroky zo štátnych dlhopisov, úroky z poskytnutých úrokov a pôžičiek a finančné prostriedky plynúce $\mathrm{z}$ grantov.

Sadzba dane právnických osôb bola znížená z 25\% na 19\% s účinnost'ou od 1. januára 2004. Štát poskytuje výnimky a oslobodenia ako sú daňové prázdniny, daňové úl'avy. Bolo vykonaných niekol'ko zmien $\mathrm{v}$ daňovom práve, aby sa prispôsobilo predpisom EÚ v oblasti priamych daní ako smernica o materských a dcérskych spoločnostiach - The parent-subsidiary directive, smernica o fúziách - merger directive, smernice o úrokoch a licenčných poplatkoch - The Interest and Royalties Directive a smernica o psporách - Savings directive. Zdanitel'ný príjem sa počíta $\mathrm{z}$ príjmu vypočítaného $\mathrm{v}$ súlade $\mathrm{s}$ účtovnými predpismi a je upravený pripočítatel'nými a odpočítatel'nými položkami na daňové účely. Pre účely odpisov, je možné použit' rovnomerný alebo zrýchlený spôsob odpisovania. Kapitálové zisky sú súčast'ou spoločnosti zdanitel'ných príjmov za bežnú činnost'. Výnosy z podielových listov a úroky z podnikových dlhopisov, certifikátov na doručitel'a, vkladové účty alebo bežné bankové účty, sú predmetom 19\% zrážkovej dane. Toto sa považuje za preddavok na daň z príjmov právnických osôb a tento príjem je zahrnutý do základu dane z príjmov právnických tuzemských spoločností. Daňové straty môžu byt' prevádzané až sedem rokov, to však platí pre umorovanie straty vykázanej za rok 2010 (pät' rokov do roku 2009). Všetky subjekty sú zdaňované zvlášt', skupinové zdanenie na Slovensku nie je možné.

Pri zist'ovaní základu dane sa vychádza z rozdielu medzi príjmami a výdavkami alebo z výsledku hospodárenia, ktorý sa d’alej upravuje. Mechanizmus úpravy výsledku hospodárenia je na Slovensku vel'mi podobný ako v Českej Republike.

Zdanitel'ným obdobím je kalendárny rok alebo hospodársky rok, ktorý nemusí byt' totožný s kalendárnym. Daňové priznanie sa podáva do konca tretieho mesiaca po skončení zdaňovacieho obdobia a správca dane môže túto dobu predĺžit' o d'alšie tri mesiace. Posledný deň lehoty pre podanie daňového priznania je súčasne aj dňom splatnosti dane. $[3,6]$

\section{Porovnanie dane z príjmov právnických osôb v porovnávaných krajinách}

Každá účtovná jednotka sa v súčasnosti snaží zefektívnit' výrobný a pracovný proces na dosiahnutie najlepších výsledkov vo svojej činnosti. Z tohto dôvodu treba upriamit' pozornost' na daňové zat'aženie v sledovanom geopolitickom priestore. Priame dane tvoria dôležitú čast' nákladov spoločnosti a je nutné prikladat' im svoj význam, aby tak 
podnikatel'ské jednotky predišli negatívnym vplyvom na výsledok hospodárenia a tým neohrozili svoju existenciu.

Nasledujúca tabul'ka porovnáva sadzbu dane z príjmov právnických osôb v spomínaných krajinách:

\begin{tabular}{|l|c|}
\hline Krajina & Sadzba dane z príjmov právnických osôb \\
\hline Česká republika & $19 \%$ \\
\hline Mad'arsko & $19 \%$ \\
\hline Pol'sko & $19 \%$ \\
\hline Slovensko & $19 \%$ \\
\hline \multicolumn{2}{|l|}{ Zdroj: vlastné spracovanie }
\end{tabular}

Výsledok hospodárenia do značnej miery ovplyvňujú odpisy, ktorými sa znižuje hodnota majetku na základe fyzického alebo morálneho opotrebenia. Odpisy sú daňovo uznaným nákladom do výšky, ktorú stanovujú legislatívne predpisy krajín. Jednotlivé krajiny majú bud' odpisové sadzby alebo odpisujú majetok na základe doby odpisovania. Konečný výsledok je v zásade rovnaký. [4]

Nasledujúca tabul'ka pojednáva o odpisových sadzbách a dobách odpisovania v štátoch prispôsobených na účely praktických modelových príkladov:

\begin{tabular}{|c|c|c|c|c|}
\hline Odpisovaný majetok & Slovensko & Česká republika & Pol'sko & Mad'arsko \\
\hline Hnutel'ný: & \multicolumn{4}{|c|}{ Doba odpisovania (odpisová sadzba) } \\
\hline Automobil & $4(25 \%)$ & $5(20 \%)$ & $5(20 \%)$ & $3,3(33 \%)$ \\
\hline Kancelársky nábytok & $6(16,7 \%)$ & $5(20 \%)$ & $5(20 \%)$ & $6,9(14,5 \%)$ \\
\hline PC zostava & $4(25 \%)$ & $3(33,3 \%)$ & $3(33,3 \%)$ & $3,3(33 \%)$ \\
\hline Výrobná linka & $6(16,7 \%)$ & $5(20 \%)$ & $7,14(14 \%)$ & $6,9(14,5 \%)$ \\
\hline Softvér & $5(20 \%)$ & $3(33,3 \%)$ & $5(20 \%)$ & $3,3(33 \%)$ \\
\hline \multicolumn{5}{|l|}{ Nehnutel'ný } \\
\hline Skladový priestor & $20(5 \%)$ & $50(2 \%)$ & $40(2,5 \%)$ & $50(2 \%)$ \\
\hline Výrobná hala & $20(5 \%)$ & $50(2 \%)$ & $40(2,5 \%)$ & $50(2 \%)$ \\
\hline
\end{tabular}

V nasledujúcej časti pomocou modelovej spoločnosti porovnáme jej daňové zat’aženie v jednotlivých krajinách. Táto spoločnost' sa zaoberá účtovníckymi a audítorskými službami v Európskej únii, ktorá má svoje pobočky v nami rozoberaných krajinách. 


\begin{tabular}{|c|c|c|c|c|c|}
\hline \multicolumn{2}{|l|}{ Krajiny } & Slovensko & $\begin{array}{l}\text { Česká } \\
\text { republika }\end{array}$ & Pol’sko & Mad'arsko \\
\hline & & \multicolumn{4}{|c|}{ Hodnota v domácich menách podl’a kurzov ECB k 16.4.2010 } \\
\hline \multicolumn{2}{|c|}{ Konverzný kurz } & $\begin{array}{c}\text { EUR/EUR } \\
=1\end{array}$ & $\begin{array}{c}\mathrm{EUR} / \mathrm{CZK}= \\
25,178\end{array}$ & $\begin{array}{c}\text { EUR/PLN= } \\
3,874\end{array}$ & $\begin{array}{c}\mathrm{EUR} / \mathrm{HUF}= \\
263,45\end{array}$ \\
\hline \multicolumn{2}{|c|}{ Výsledok hospodárenia } & 20000 & 503560 & 77480 & 5269000 \\
\hline \multirow{4}{*}{$\begin{array}{l}\text { Odpisovaný } \\
\text { majetok }\end{array}$} & $\begin{array}{l}\text { Účtovné } \\
\text { softvéry }\end{array}$ & 5000 & 125890 & 19370 & 1317250 \\
\hline & $\begin{array}{l}\text { Počítačové } \\
\text { zostavy }\end{array}$ & 10000 & 251780 & 38740 & 2634500 \\
\hline & $\begin{array}{l}\text { Kancelársky } \\
\text { nábytok }\end{array}$ & 3500 & 88123 & 13559 & 922075 \\
\hline & Automobil & 40000 & 1007120 & 154960 & 10538000 \\
\hline
\end{tabular}

Zdroj: Blaščák,J.: Daňové zat’aženie modelového podniku v oblasti služieb vo V4. [Online]. [Citované 2010-1207]. Dostupné na: < http://www.podnikajte.sk/prevadzka-firmy/category/dane-a-odvody/article/danovezatazenie-sluzby-v4-2010.xhtml $>$

Na základe týchto údajov d'alej určíme ako budú odpisy účtovnej jednotky vplývat' na výpočet dane z príjmov právnických osôb v roku 2010. Rozdiel medzi účtovnými a daňovými odpismi bude tvorit' $\mathrm{v}$ prípade kladného výsledku pripočítatel'nú položku a v prípade záporného odpočítatel'nú položku. V nasledujúcich tabul'kách vypočítame odpisy jednotlivých druhov majetku najskôr v domácich menách a následne prepočítame na euro.

Spoločnost' si v internej smernici stanovila dobu odpisovania osobného automobilu na 6 rokov, počítačových zostáv na 5 rokov, kancelárskeho nábytku na 4 roky a softvéru na dobu 4 rokov. [4]

V nasledujúcej tabul'ke vypočítame ročné účtovné a daňové odpisy osobného automobilu:

\begin{tabular}{|l|r|r|r|r|}
\hline $\begin{array}{l}\text { Odpisy majetku: } \\
\text { Automobil - VW Passat } \\
\text { 2,0TDi (100kW) }\end{array}$ & $\begin{array}{c}\text { Slovensko } \\
\text { (EUR) }\end{array}$ & \multicolumn{1}{c|}{$\begin{array}{c}\text { Česká } \\
\text { republika } \\
\text { (CZK) }\end{array}$} & \multicolumn{1}{c|}{$\begin{array}{c}\text { Pol'sko } \\
\text { (PLN) }\end{array}$} & \multicolumn{1}{c|}{$\begin{array}{c}\text { Mad'arsko } \\
\text { (HUF) }\end{array}$} \\
\hline Obstarávacia cena & 40000 & 1007120 & 154960 & 10538000 \\
\hline Odpisové sadzby & 0,25 & 0,2 & 0,2 & 0,33 \\
\hline Účtovný odpis & 6667 & 167853 & 25827 & 1756333 \\
\hline Ročný odpis daňový & 10000 & 201424 & 30992 & 3477540 \\
\hline Účtovný odpis v EUR & 6667 & 6667 & 6667 & 6667 \\
\hline Daňový odpis v EUR & 10000 & 8000 & 8000 & 13200 \\
\hline Rozdiel v odpisoch & -3333 & -1333 & -1333 & -6533 \\
\hline
\end{tabular}

Zdroj: Blašč́k,J.: Daňové zat’aženie modelového podniku v oblasti služieb vo V4. [Online]. [Citované 2010-1207]. Dostupné na: < http://www.podnikajte.sk/prevadzka-firmy/category/dane-a-odvody/article/danovezatazenie-sluzby-v4-2010.xhtml>

V tejto tabul'ke sme zistili výšku odpočítatel'nej položky v porovnávaných krajinách vzhl'adom na odpis automobilu. Z uvedeného vyplýva, že najvýraznejší je rozdiel medzi účtovnými a daňovými odpismi v Mad’arsku, odpočítatel’ná položka bude vo výške 6633 Eur. 
Ďalším príkladom bude výpočet ročných účtovných a daňových odpisov počítačových zostáv:

\begin{tabular}{|l|r|r|r|r|}
\hline $\begin{array}{l}\text { Odpisy majetku: Počítačové } \\
\text { zostavy }\end{array}$ & $\begin{array}{c}\text { Slovensko } \\
\text { (EUR) }\end{array}$ & \multicolumn{1}{c|}{$\begin{array}{c}\text { Česká } \\
\text { republika } \\
\text { (CZK) }\end{array}$} & \multicolumn{1}{c|}{$\begin{array}{c}\text { Pol'sko } \\
\text { (PLN) }\end{array}$} & \multicolumn{1}{c|}{$\begin{array}{c}\text { Mad'arsko } \\
\text { (HUF) }\end{array}$} \\
\hline Obstarávacia cena & 10000 & 251780 & 38740 & 2634500 \\
\hline Odpisové sadzby & 0,25 & 0,333 & 0,3 & 0,33 \\
\hline Účtovný odpis & 2000 & 50356 & 7748 & 526900 \\
\hline Ročný odpis daňový & 2500 & 83843 & 11622 & 869385 \\
\hline Účtovný odpis v EUR & 2000 & 2000 & 2000 & 2000 \\
\hline Daňový odpis v EUR & 2500 & 3330 & 3000 & 3300 \\
\hline Rozdiel v odpisoch & -500 & -1330 & -1000 & -1300 \\
\hline
\end{tabular}

Zdroj: Blaščák,J.: Daňové zat’aženie modelového podniku v oblasti služieb vo V4. [Online]. [Citované 2010-1207]. Dostupné na: < http://www.podnikajte.sk/prevadzka-firmy/category/dane-a-odvody/article/danovezatazenie-sluzby-v4-2010.xhtml>

V tejto tabul'ke sme zistili výšku odpočítatel'nej položky v porovnávaných krajinách vzhl'adom na odpis počítačových zostáv. Z uvedeného vyplýva, že najväčší je rozdiel medzi účtovnými a daňovými odpismi v Českej republike, odpočítatel'ná položka bude vo výške 1330 Eur a najmenší na Slovensku v hodnote 500 Eur.

Výpočet ročných účtovných a daňových odpisov kancelárskeho nábytku

\begin{tabular}{|l|r|r|r|r|}
\hline $\begin{array}{l}\text { Odpisy majetku: Kancelársky } \\
\text { nábytok }\end{array}$ & $\begin{array}{c}\text { Slovensko } \\
\text { (EUR) }\end{array}$ & \multicolumn{1}{c|}{$\begin{array}{c}\text { Česká } \\
\text { republika } \\
\text { (CZK) }\end{array}$} & \multicolumn{1}{c|}{$\begin{array}{c}\text { Pol'sko } \\
\text { (PLN) }\end{array}$} & \multicolumn{1}{c|}{$\begin{array}{c}\text { Mad'arsko } \\
\text { (HUF) }\end{array}$} \\
\hline Obstarávacia cena & 3500 & 88123 & 13559 & 922075 \\
\hline Odpisové sadzby & 0,167 & 0,2 & 0,2 & 0,145 \\
\hline Účtovný odpis & 875 & 22031 & 3390 & 230519 \\
\hline Ročný odpis daňový & 585 & 17625 & 2712 & 133701 \\
\hline Účtovný odpis v EUR & 875 & 875 & 875 & 875 \\
\hline Daňový odpis v EUR & 585 & 700 & 700 & 508 \\
\hline Rozdiel v odpisoch & 290 & 175 & 175 & 368 \\
\hline
\end{tabular}

Zdroj: Blaščák,J.: Daňové zat’aženie modelového podniku v oblasti služieb vo V4. [Online]. [Citované 2010-1207]. Dostupné na: < http://www.podnikajte.sk/prevadzka-firmy/category/dane-a-odvody/article/danovezatazenie-sluzby-v4-2010.xhtml>

V tejto tabul'ke sme zistili výšku pripočítatel'nej položky v porovnávaných krajinách vzhl'adom na odpis kancelárskeho nábytku. V uvedenej tabul'ke môžeme vidiet', že v krajinách bude odpis kancelárskeho nábytku tvorit' pripočítatel'nú položku k výsledku hospodárenia a to v najväčšej miere v Mad'arsku a najmenej v Českej republike a Pol'sku. 
Ročné účtovné a daňové odpisy účtovníckeho softvéru budú vyzerat' nasledovne:

\begin{tabular}{|l|r|r|r|r|}
\hline $\begin{array}{l}\text { Odpisy majetku: Účtovnícky } \\
\text { softvér }\end{array}$ & \multicolumn{1}{c|}{$\begin{array}{c}\text { Slovensko } \\
\text { (EUR) }\end{array}$} & \multicolumn{1}{c|}{$\begin{array}{c}\text { Česká } \\
\text { republika } \\
\text { (CZK) }\end{array}$} & \multicolumn{1}{c|}{$\begin{array}{c}\text { Pol'sko } \\
\text { (PLN) }\end{array}$} & \multicolumn{1}{c|}{$\begin{array}{c}\text { Mad'arsko } \\
\text { (HUF) }\end{array}$} \\
\hline Obstarávacia cena & 5000 & 125890 & 19370 & 1317250 \\
\hline Odpisové sadzby & 0,2 & 0,333 & 0,2 & 0,33 \\
\hline Účtovný odpis & 1250 & 31473 & 4843 & 329313 \\
\hline Ročný odpis daňový & 1000 & 41921 & 3874 & 434693 \\
\hline Účtovný odpis v EUR & 1250 & 1250 & 1250 & 1250 \\
\hline Daňový odpis v EUR & 1000 & 1665 & 1000 & 1650 \\
\hline Rozdiel v odpisoch & 250 & -415 & 250 & -400 \\
\hline
\end{tabular}

Zdroj: Blaščák,J.: Daňové zataženie modelového podniku v oblasti služieb vo V4. [Online]. [Citované 2010-1207]. Dostupné na: < http://www.podnikajte.sk/prevadzka-firmy/category/dane-a-odvody/article/danovezatazenie-sluzby-v4-2010.xhtml>

V tejto tabul'ke sme zistili výšku odpočítatel'nej položky v porovnávaných krajinách vzhl'adom na odpis účtovníckeho softvéru. Z tejto tabul'ky vyplýva, že v niektorých krajinách bude odpis tvorit' pripočítatel'nú položku (a to v Slovenskej republike a Pol'sku a to v rovnakej hodnote) a v niektorých odpočítatel'nú položku (a to v Českej republike a Mad'arsku).

Zhodnotenie vplyvu pripočítatel'ných a odpočítatel'ných položiek na výsledok hospodárenia a výšku dane a daňové zat'aženie podniku vzhl'adom na výsledok hospodárenia:

\begin{tabular}{|c|c|c|c|c|}
\hline Krajina & Slovensko & $\begin{array}{l}\text { Česká } \\
\text { republika }\end{array}$ & Pol'sko & Mad'arsko \\
\hline Výsledok hospodárenia & 20000 & 20000 & 20000 & 20000 \\
\hline \multicolumn{5}{|l|}{ Pripočítatel'né položky: } \\
\hline Výdavky na reprezentáciu & 800 & 800 & 800 & 800 \\
\hline Dary & 300 & 300 & 300 & 300 \\
\hline \multicolumn{5}{|l|}{ Odpočítatel'né položky: } \\
\hline $\begin{array}{l}\text { Predpis úrokov } \mathrm{z} \text { omeškaných } \\
\text { platieb klientov }\end{array}$ & -900 & -900 & -900 & -900 \\
\hline $\begin{array}{ll}\text { Platba dane } & \text { z prenajatej } \\
\text { nehnutel'nosti }\end{array}$ & -300 & -300 & -300 & -300 \\
\hline \multicolumn{5}{|c|}{ Rozdiely účtovných a daňových odpisov } \\
\hline Účtovné softvéry & +250 & -415 & +250 & -400 \\
\hline Počítačové zostavy & -500 & -1330 & -1000 & -1300 \\
\hline Kancelársky nábytok & +291 & +175 & +175 & $+367,5$ \\
\hline Osobné automobily & -3333 & -1333 & -1333 & -6533 \\
\hline VH po zohl'adnení položiek & 16608 & 16997 & 17992 & 12035 \\
\hline Sadzba dane z príjmov & $19 \%$ & $19 \%$ & $19 \%$ & $19 \%$ \\
\hline Splatná daň & 3155,4 & 3229,4 & 3418,5 & 2286,7 \\
\hline Č́stý výsledok hospodárenia & 16845 & 16771 & 16582 & 9748,3 \\
\hline $\begin{array}{l}\text { Daňové zat'aženie podnikatel'ov } \\
\text { v oblasti služieb }\end{array}$ & $15,78 \%$ & $16,15 \%$ & $17,09 \%$ & $11,43 \%$ \\
\hline Poradie & 2. & 3. & 4. & 1. \\
\hline
\end{tabular}

Zdroj: Blaščk,J.: Daňové zat’aženie modelového podniku v oblasti služieb vo V4. [Online]. [Citované 2010-1207]. Dostupné na: < http://www.podnikajte.sk/prevadzka-firmy/category/dane-a-odvody/article/danovezatazenie-sluzby-v4-2010.xhtml> 


\section{Záver}

Napriek tomu že v porovnávaných krajinách je stanovená rovnaká daňová sadzba, po zohl'adnení odpočítatel'ných a pripočítatel'ných položiek je výsledok hospodárenia a teda aj daňové zat'aženie v každej krajine iné, najnižšie v Mad'arsku a najvyššie v Pol'sku. V oblasti služieb je teda Mad'arsko vd'aka výhodne nastavenej odpisovej politike najvhodnejšiou krajinnou. Slovensko svojou daňou z príjmov právnických osôb je v konkurencii s vyššie porovnávanými štátmi, toto vedenie sa dá pripísat' spôsobu znižovania základu dane o odpočítatel'né položky. Toto je ovplyvnené spôsobom výpočtu odpisov, ktoré ovplyvňuje daňová legislatíva na Slovensku.

\section{Literatúra}

[1] Bieliková,A. - Štofková,K.: Dane, Edis, Žilina, 2010, ISBN 978-80-554-0169-0

[2] Široký, J.: Daně v Evropské unii, Linde Praha, Praha, 2009, ISBN 978-80-7201-746-1

[3] Krátka,L.: Výskum štruktúry a obsahu analytickej evidencie nákladov pre účely výpočtu a kontroly daní v siet’ových podnikoch, [písomná práca k dizertačnej skúške], Fakulta prevádzky a ekonomiky dopravy a spojov Žilinskej univerzity v Žiline, Žilina, 2009

[4] Blaščák,J.: Daňové zat’ǎ̌enie modelového podniku v oblasti služieb vo V4. [Online]. [Citované 2010-12-07]. Dostupné na: < http://www.podnikajte.sk/prevadzkafirmy/category/dane-a-odvody/article/danove-zatazenie-sluzby-v4-2010.xhtml>

[5] Blaščák,J.: : Porovnanie priamych daní v krajinách V4 v roku 2010. [Online]. [Citované 2010-12-07]. Dostupné na: http://www.podnikajte.sk/prevadzka-firmy/category/dane-aodvody/list/2/article/porovnanie-priame-dane-v4-2010.xhtml

[6] Eurostat: Taxation trends in the European Union, European Union 2010, ISBN 978-9279-15801-8 